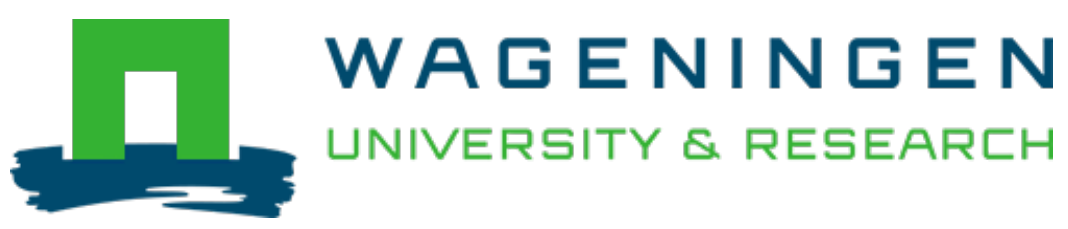

\title{
Nutritional Plasticity of the Black Soldier Fly (Hermetia Illucens) in Response to Artificial Diets Varying in Protein and Carbohydrate Concentrations
}

\author{
Journal of Insects as Food and Feed \\ Barragan-Fonseca, K.B.; Gort, G.; Dicke, M.; Loon, J.J.A. \\ https://doi.org/10.3920/JIFF2020.0034
}

This article is made publicly available in the institutional repository of Wageningen University and Research, under the terms of article $25 \mathrm{fa}$ of the Dutch Copyright Act, also known as the Amendment Taverne. This has been done with explicit consent by the author.

Article 25 fa states that the author of a short scientific work funded either wholly or partially by Dutch public funds is entitled to make that work publicly available for no consideration following a reasonable period of time after the work was first published, provided that clear reference is made to the source of the first publication of the work.

This publication is distributed under The Association of Universities in the Netherlands (VSNU) 'Article $25 \mathrm{fa}$ implementation' project. In this project research outputs of researchers employed by Dutch Universities that comply with the legal requirements of Article $25 \mathrm{fa}$ of the Dutch Copyright Act are distributed online and free of cost or other barriers in institutional repositories. Research outputs are distributed six months after their first online publication in the original published version and with proper attribution to the source of the original publication.

You are permitted to download and use the publication for personal purposes. All rights remain with the author(s) and / or copyright owner(s) of this work. Any use of the publication or parts of it other than authorised under article $25 \mathrm{fa}$ of the Dutch Copyright act is prohibited. Wageningen University \& Research and the author(s) of this publication shall not be held responsible or liable for any damages resulting from your (re)use of this publication.

For questions regarding the public availability of this article please contact openscience.library@wur.nl 


\title{
Nutritional plasticity of the black soldier fly (Hermetia illucens) in response to artificial diets varying in protein and carbohydrate concentrations
}

\author{
K.B. Barragan-Fonseca ${ }^{1,2 *}$, G. Gort ${ }^{3}$, M. Dicke ${ }^{1}$ and J.J.A. van Loon ${ }^{1}$ \\ ${ }^{1}$ Laboratory of Entomology, Wageningen University, P.O. Box 16, 6700 AA, Wageningen, the Netherlands; ${ }^{2}$ Centro \\ de Investigación de Artrópodos terrestres - CINAT, Facultad de Medicina Veterinaria y de Zootecnia, Universidad \\ Nacional de Colombia, 111321 Bogotá, Colombia; ${ }^{3}$ Biometris, Wageningen University, P.O. Box 16, 6700 AA, Wageningen, \\ the Netherlands; kbbarraganf@unal.edu.co
}

Received: 30 April 2020 / Accepted: 8 June 2020

(c) 2020 Wageningen Academic Publishers

\section{RESEARCH ARTICLE}

\begin{abstract}
Protein $(\mathrm{P})$ and carbohydrate $(\mathrm{C})$ concentrations present in food affect larval performance, larval body nutrient concentration, and fecundity of the black soldier fly (BSF). We substantially expanded the range of dietary P- and C-concentrations investigated thus far to assess the effects of nutritionally - unbalanced diets on BSF larval and adult life-history traits, and on larval body protein and lipid concentrations. Twenty five artificial diets varying in their $\mathrm{P}$ - and $\mathrm{C}$-concentration and ratio were formulated. We tested five macronutrient $(\mathrm{P}+\mathrm{C})$ concentrations $(5,15,25$, 50 and $75 \%)$ and five $\mathrm{P}: \mathrm{C}$ ratios (1:1, 1:2, 1:4, 2:1 and 4:1). BSF performance was affected by $\mathrm{P}+\mathrm{C}$-concentration rather than by $\mathrm{P}: \mathrm{C}$ ratios. A P-concentration between 10 and $15 \%$ and a C-concentration between 10 and $60 \%$ supported high larval and adult performance. P-concentration is limiting for most of the performance variables, however, a P-concentration higher than $37 \%$ reduced larval survival. C-concentration affected egg production more strongly than $\mathrm{P}$-concentration. Overall, at $\mathrm{P}+\mathrm{C}$ values of 25 and $50 \%$, and $\mathrm{P}: \mathrm{C}$ ratios $1: 2$ and $1: 4$ resulted in the highest values of most of the larval and adult performance variables we measured. For the protein and carbohydrate sources tested, dietary macronutrient concentrations significantly affected larval and adult performance of BSF in different ways. These results show a remarkable degree of nutritional plasticity, and point to the relevance of differentiating the formulation of diets to achieve maximal larval yield, high body protein or high body lipid accumulation or high adult emergence and egg production.
\end{abstract}

Keywords: larval performance, body nutrient concentration, response surface model, fitness

\section{Introduction}

Nutrition profoundly affects animal physiology, behaviour and performance, which in turn impact their life-history traits and ecology (Lihoreau et al., 2015). During foraging insects experience nutritional constraints as they are confronted with food sources that may contain levels and proportions of protein $(\mathrm{P})$ and carbohydrate $(\mathrm{C})$ that deviate considerably from values optimal for growth and fitness. The Nutritional Geometry Framework (NGF) has become the standard approach to model the effects of varying concentrations of nutrient mixtures on physiology, behaviour and ecology of insects (Raubenheimer and Simpson, 1997, 2018). The Nutritional Geometry Frame- work approach maps the consequences of ingestion of $\mathrm{P}$ and $\mathrm{C}$ in certain amounts and ratios for growth and reproduction onto the plane that represents the range of combinations of $\mathrm{P}$ and $\mathrm{C}$ contents, resulting in surfaceresponse models graphically depicting the response to deviations to the optimal values.

Saprophagous insects feed on decaying organic material and the associated microbiota. Although these insects are considered instrumental in ecosystem nutrient flow (Price, 1997) their nutritional ecology has not been explored to the same extent as for plant-feeding insects (Raubenheimer and Simpson, 2018). The black soldier fly (BSF; Hermetia illucens (L.); Diptera: Stratiomyidae) is a generalist saprophagous 
species that has received increasing attention over the past decade due to its versatility in converting decaying organic matter into high-quality animal protein that can be used as animal feed (Gold et al., 2018). Larval diet affects its reproductive potential since nutrient accumulation largely occurs during the larval stage (Gobbi et al., 2013).

Previous studies on BSF nutrition pointed to regulation of larval protein concentration within narrow limits whereas larval crude fat concentration was strongly affected by diet nutrient concentration (reviewed by Barragan-Fonseca et al., 2017a). However, the range of concentrations and ratios of dietary protein and carbohydrate tested thus far was limited to the reported range of these macronutrients in food sources utilised by BSF in nature (Barragan-Fonseca et al. 2019; Cammack and Tomberlin, 2017; Gold et al., 2018). The objective of this study was to investigate the influence of a much wider range of dietary protein and digestible carbohydrate concentrations on both larval and adult life-history traits of BSF, and on larval body nutrient concentrations. We investigated macronutrient effects for five $\mathrm{P}+\mathrm{C}$ concentrations and five $\mathrm{P}: \mathrm{C}$ ratios in a full crossover design as realised in 25 chemically defined diets to assess larval and adult performance and regulation of larval body nutrient concentration.

\section{Materials and methods}

\section{Experimental insects}

Hermetia illucens (L.) (Diptera: Stratiomyidae) eggs were obtained from a colony maintained at constant conditions in a climate room $\left(27 \pm 1^{\circ} \mathrm{C}, 70 \% \mathrm{RH}, \mathrm{L} 12\right.$ :D12) at the Laboratory of Entomology, Wageningen University, the Netherlands. The diet of the BSF larvae colony was standard chicken feed (Opfokmeel Farmfood, Agruniek Rijnvallei Voer BV, Wageningen, the Netherlands).

\section{Experimental design}

Twenty five artificial diets varying in protein $(\mathrm{P})$ and digestible carbohydrate $(\mathrm{C})$ concentration and ratio were formulated. We tested five total macronutrient concentrations, the sum of $P$ and $C$ concentrations: $5,15,25$, 50 and $75 \%$, and five $P: C$ ratios (1:1, 1:2, 1:4, 2:1 and 4:1). The diets were formulated by including casein as protein source (Bio-connect, Huissen, the Netherlands), which contains all the amino acids essential for insects in high quantities and well-balanced proportions (Cohen, 2004). Starch (Duchefa Biochemie BV, Haarlem, the Netherlands) was included as main source of carbohydrates (Cohen, 2004); linseed oil $(0.6 \%)$ was added as a source of linoleic acid; Wesson's mineral mix (Sigma-Aldrich, Zwijndrecht, the Netherlands) (2.3\%); Vanderzant's vitamin mix (Sigma-Aldrich) (4.5\%). Cholesterol $(0.12 \%)$ was added as main sterol source. Insects cannot synthesise sterols and they must be taken up from the diet. Linoleic, mineral and vitamin content was based on a combination of micronutrient mixtures found in literature (New Zealand general diet, the Gainesville diet and Chemical Specialties Manufacturers Association (CSMA) diet. The remaining proportion was cellulose (Alphacel non-nutritive bulk; Bio-connect), considered to be a poorly digestible bulk agent.

The 25 diets served as experimental treatments. Per dietary treatment three replicates were set up in three serial time blocks. Each replicate of each treatment had 100 larvae hatched less than $24 \mathrm{~h}$ prior to being introduced on the diets. A fixed feeding ration of $0.8 \mathrm{~g}$ (dry matter basis) of diet per larva was employed. This amount of diet was added once at the beginning of the experiment, as a preliminary experiment had shown that larvae fed once rather than three times per week reached a higher biomass. The total amount of feed was $80 \mathrm{~g}$ per $750 \mathrm{ml}$ container. The amount of water added at the start of the experiment was $120 \mathrm{~g}$ to the $75 \%$ macronutrient treatments, 140 to $50 \%, 160$ to $25 \%$, 180 to $15 \%$, and 200 to $5 \%$ to account for the greater water absorption by higher amounts of cellulose, to obtain $60-70 \%$ of moisture and a similar consistency for all the treatments. The plastic containers were covered with transparent plastic lids with 90 holes (diameter $0.05 \mathrm{~cm}$ each) for ventilation during the first 4 days. After 4 days, the lid was replaced by a lid with a window of ca. $3 \times 7 \mathrm{~cm}$ in the centre and a nylon pantyhose of 20 denier stretched around the container, so that no larvae could escape. The feeding experiments were conducted in a climatic room $\left(4.5 \mathrm{~m}^{2}\right)$ and maintained at constant conditions $\left(27 \pm 1^{\circ} \mathrm{C}, 70 \pm 2 \%\right.$ r.h., L12:D12). In order to eliminate positional effects, all containers were randomly relocated three times per week.

\section{Larval life-history traits}

Larvae were harvested when at least $40 \%$ of the larvae were observed to have reached the pre-pupal stage, as apparent from the characteristic black cuticle of prepupae (May, 1961). Development time was taken as the number of days between the start of the experiment, and the day of harvesting. All animals from each container were harvested with forceps, counted, and weighed collectively. Larvae were washed under running water to remove residues consisting of left-over feed and faeces, their integument dried with paper tissues, and their weight registered as BSF larvae yield ( $\mathrm{g}$ fresh matter) on a precision balance (Ohaus, Adventurer Pro AV313, Parsippany, USA, precision \pm 0.001 g). To determine survival rate, the number of live BSF at the end of the experiment (day of harvesting) was divided by the initial number of larvae per replicate. To determine the survival rate until the adult stage, the number of BSF adults eclosed was divided by the initial number of larvae per replicate (i.e. 100). The development time until the adult stage was taken as the number of days between the start of the experiment, and the day the first adult was observed. 


\section{Adult life history traits}

Thirty (15 females and 15 males) newly eclosed $(<12 \mathrm{~h}$ old) adult BSF from each container were released into a BugDorm- 1 cage $(30 \times 30 \times 30$ cm, MegaView Science Co. Ltd., Taichung, Taiwan) and kept in a climate room under controlled conditions $\left(27 \pm 1^{\circ} \mathrm{C}, 70 \pm 2 \%\right.$ r.h., L12:D12). Per dietary treatment three replicates were set up. Adults were provided ad libitum with water through a cylinder of filter paper extending from a glass water bottle and crystalline sugar sprinkled on a plastic tray. Two days after eclosion, a mixture of sand (25 g), BSF larvae substrate from the rearing $(25 \mathrm{~g})$ and water $(25 \mathrm{ml})$ in a plastic container $(150 \mathrm{ml})$ was offered for oviposition. The surface of each container had one corrugated cardboard $(4(\mathrm{~h}) \times 9(\mathrm{l}) \mathrm{cm})$, as a substrate for egg laying. Every two days the pieces of cardboards were removed from all containers and substituted by new ones. In order to determine fecundity, number of egg masses collected form the cardboard pieces, and percentage of larval hatching were recorded. We also measured surface of viable egg masses $\left(\mathrm{mm}^{2}\right)$ as a proxy of viable egg number; thus we registered the surface of all the egg masses we collected, but only took in account the surface of those eggs masses that hatched and produced F1; this variable was called egg yield $\left(\mathrm{mm}^{2}\right)$. Adult weight $(<24 \mathrm{~h}$ old) was determined on a precision balance (Mettler Toledo, NewClassicML, Greifensee, Switzerland, precision $\pm 0.001 \mathrm{~g})$. Longevity was determined by placing adults $(<24 \mathrm{~h}$ old $)$ in plastic containers (200 $\mathrm{ml}$ ) and counting the number of days between placing them in the container without water and sugar, and the day they died. In order to analyse BSF fitness, we used a proxy for rate of population growth, denoted as $r_{\mathrm{p}}$. Because we did not quantify egg numbers per female the intrinsic rate of population increase $r_{\mathrm{m}}$ could not be determined. The formula we used to calculate $r_{\mathrm{p}}$ was $(\operatorname{lnEY}) / \mathrm{T}$, where EY is egg yield $\left(\mathrm{mm}^{2}\right)$ and $\mathrm{T}$ is development time until adult stage (days).

\section{Proximate chemical analysis of larvae}

Samples were stored in a freezer $\left(-25^{\circ} \mathrm{C}\right)$ until all replicates were harvested. For each replicate of each of the 25 treatments, larvae were analysed for dry matter (DM), crude protein, and crude fat concentrations at the Animal Nutrition Laboratory of Wageningen University. The samples were oven-dried at $70{ }^{\circ} \mathrm{C}$ until constant weight and homogenised by grinding the samples in an ultracentrifugal mill (Retsch ZM 200, Haan, Germany). Crude protein $(6 \cdot 25 \times \mathrm{N}$-concentration) was determined using the Kjeldahl method (ISO 5983-1, 2005) and crude fat was analysed according to the Berntop method (ISO 6492, 1999).

\section{Statistical analysis}

To examine how protein and carbohydrate levels affected the response variables of insect performance and larval body concentration we split the analysis into two parts, studying: (1) the effects of the factors total concentration of $\mathrm{P}$ and $\mathrm{C}(\mathrm{P}+\mathrm{C})$ and their ratio $(\mathrm{P}: \mathrm{C})$, using two-way ANOVA with factors $P+C$ and $P: C$; (2) the effects of concentration of $\mathrm{P}$ and of $\mathrm{C}$, using thin plate spline models and quadratic response surface models. The two-way ANOVA of the first part follows closely the actual experimental design, which has the two crossed factors $\mathrm{P}+\mathrm{C}$ (with levels 5, 15, 25, 50 and $75 \%$ ) and P:C (with levels 1:1, 1:2, 1:4, 2:1 and 4:1).

Instead of showing full ANOVA tables for the two analysis parts, we visualised the sums of squares as stacked barplots, thereby showing relative importance of the sources of variations. For part 1 relative importance of the main effects of $\mathrm{P}+\mathrm{C}(4 \mathrm{df})$ and $\mathrm{P}: \mathrm{C}(4 \mathrm{df})$, their interaction $(13 \mathrm{df})$ and the residual error (44 df for larval data, 30 for larval body composition data, $33 \mathrm{df}$ for adult data) are shown. For part 2 relative importance of linear and quadratic of $\mathrm{P}(2 \mathrm{df})$, linear and quadratic effects of $\mathrm{C}(2 \mathrm{df})$, interaction between $\mathrm{P}$ and $\mathrm{C}$ (1 df), lack of fit (higher order effects and interactions; $16 \mathrm{df}$ for larval data, $15 \mathrm{df}$ for larval body concentration and adult data), and residual error (44, 30 or $33 \mathrm{df}$, as described above). Significance level was set at $P<0.05$.

In part 2, we first made response surface plots using thinplate splines, using the R package fields (Nychka, 2017) in $\mathrm{R}$ version 3.3.3 (R-Core-Team, 2017). However, the thinplate spline approach does not allow the inclusion of block effects, as we have here: in the experimental design for larval and adult data, a temporal block was present, which was partially confounded with dietary levels. Therefore, we also fitted quadratic response surface models using the $\mathrm{R}$ package rsm (Lenth, 2009). Results were summarised with overall F-tests (testing for any effect at all), and with F-tests for linear effects of $\mathrm{P}$ and of $\mathrm{C}$, for quadratic effects of $\mathrm{P}$ and of $\mathrm{C}$ (after linear effects of $\mathrm{P}$ and $\mathrm{C}$ ), for interaction of $\mathrm{P}$ and $C$ (after linear effects of $P$ and $C$ ), and lack of fit for the quadratic response surface model (indicating higher order effects and interactions of $\mathrm{P}$ and $\mathrm{C}$ ). For contour plots the $\mathrm{P}-\mathrm{C}$ interaction and quadratic terms were removed from the model if found to be unnecessary $(P>0.05)$. If lack of fit was significant $(P<0.05)$, terms of order three were included to arrive at a well-fitting model. Models with $\log (\mathrm{P})$ and $\log (\mathrm{C})$ as regressors were fitted for comparison and selected if shown to be superior (higher $\mathrm{R}^{2}$ or lower lack of fit). For all response variables the block effect was initially included in the quadratic response surface models, but removed if found to be insignificant $(P>0.05)$. For all fitted models residual plots were made to check for potential outliers and deviations of assumptions (i.e. approximate normality and constant variance). The relationship between egg mass production and longevity with adult weight was studied using the Pearson correlation coefficient. 


\section{Results}

The analysis of the relative importance of dietary concentrations and ratio of protein and carbohydrate (Figure 1) demonstrated that BSF performance was more affected by total concentration of carbohydrate and protein $(\mathrm{P}+\mathrm{C})$ than by $\mathrm{P}: \mathrm{C}$ ratio. The variation in larval crude fat, larval development time, larval yield, adult weight, and adult development time was explained for more than 50\% by $\mathrm{P}+\mathrm{C}$. For all response variables the interaction between $\mathrm{P}+\mathrm{C}$ and $\mathrm{P}: \mathrm{C}$ ratio explained more variation than the main effect $P: C$ ratio.

Our analysis of the relative importance of the two macronutrients (Figure 2) demonstrates that $\mathrm{P}$ and $\mathrm{C}$-concentration explain most variation in larval development time and larval crude fat, with P-concentration having a stronger effect ( $>50 \%$ of variation explained). Similarly, P-concentration had a stronger effect than C-concentration on adult emergence, development time until adult stage, larval survival, and larval crude protein. On the other hand, $\mathrm{C}$-concentration had a stronger effect than P-concentration on adult weight, egg yield and egg mass. P- and C-concentration had similar effects on larval yield, rate of population growth and adult longevity. It should be noted that for larval crude protein and adult longevity the models explain a low percentage of variation. The effects of the interaction PxC are only moderate for most of the variables; only for larval yield a substantial part of variation is explained by the interaction.

\section{Larval life-history traits}

Larvae were not able to survive at $\mathrm{P}+\mathrm{C} 75 \%$ and $\mathrm{P}: \mathrm{C}$ ratios 1:1, 2:1 and 4:1 (37.5, 50 and 60\% P-concentration, respectively). Therefore, those treatments were excluded from performance measurement analysis for both larvae and adults. Survival rate showed a strong linear effect of protein concentration $(P<0.001)$ and carbohydrate concentration $(P<0.001)$, but also some higher order effects (Table 1$)$ and was higher at $15 \%$ diets at all $P: C$ ratios, decreasing as the nutrient concentration increased (Figure 3A). Development time showed strongest effects of $\mathrm{P}$ and $\mathrm{P}^{2}$ (both $P<0.001$ ), smaller effects of $\mathrm{C}$ and $\mathrm{C}^{2}$, and a very strong interaction

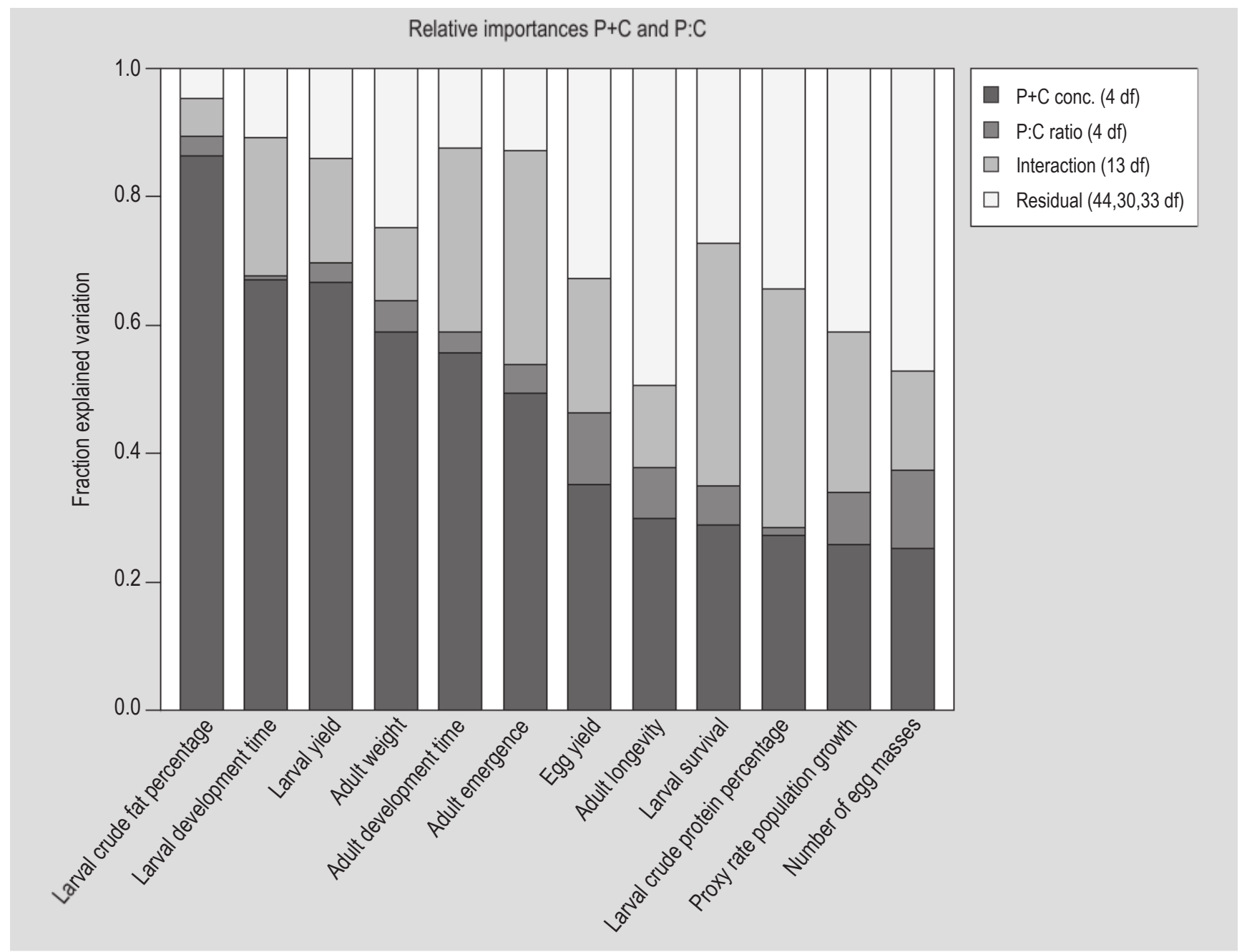

Figure 1. Relative importance of factors total protein and carbohydrate $(P+C)$ concentration and $P: C$ ratio on larval and adult performance variables of the black soldier fly Hermetia illucens. $\mathrm{df}=$ degrees of freedom. 


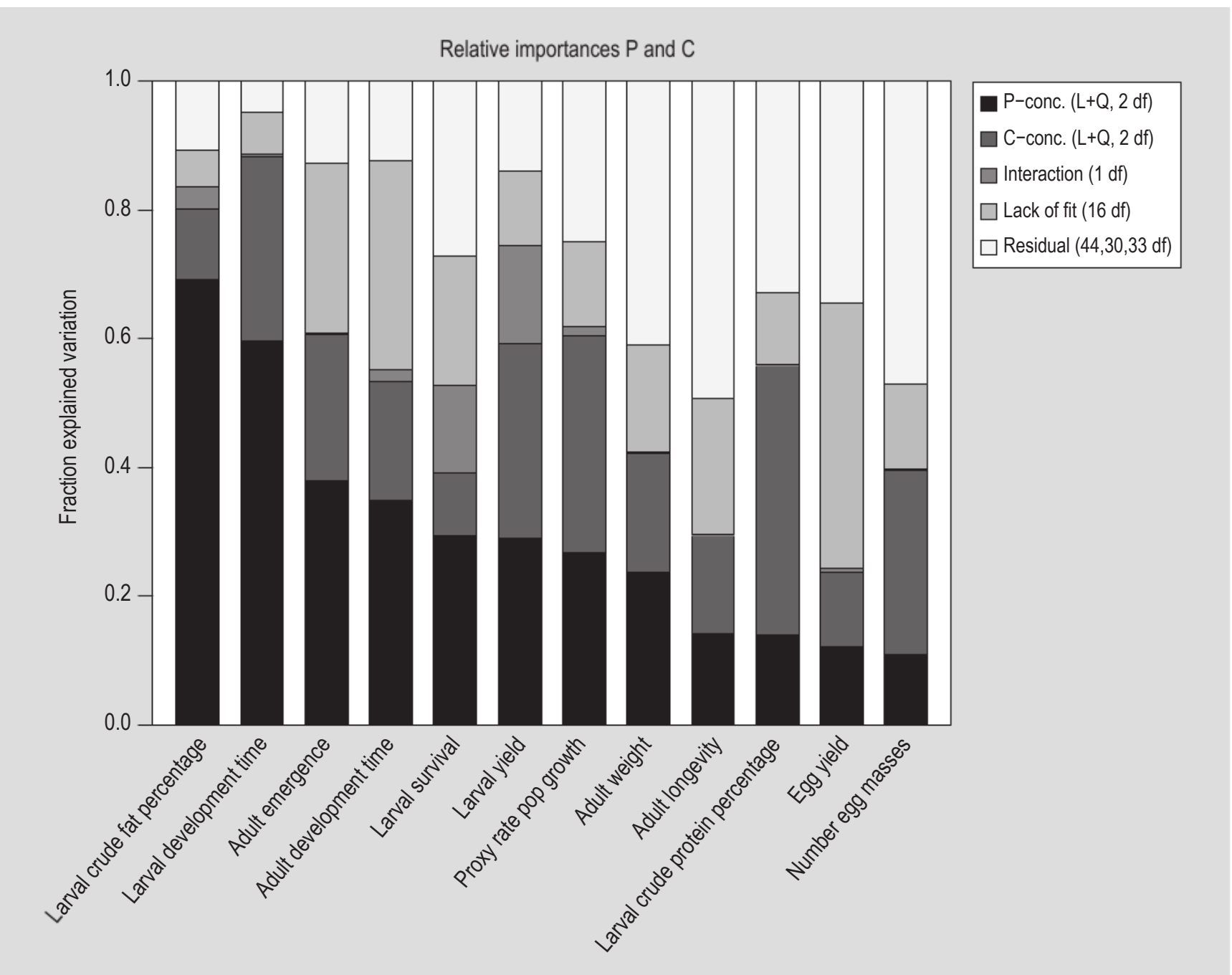

Figure 2. Relative importance of protein $(P)$-concentration, carbohydrate $(C)$-concentration and their interaction $(P \times C)$ on larval, adult and larval body nutrient concentration performance measurements of the black soldier fly. $L=$ linear; $Q=q u a d r a t i c ; d f=$ degree of freedom; models for larval development time and larval survival contain block effect, leading to $15 \mathrm{df}$ for lack of fit term.

effect $(P<0.001)$ (Table 1). Development time was shortest on $15 \%$ diets with high protein concentration, but it was longest at all 5\% diets, mainly the P:C 1:4 diet with the lowest protein concentration and at $\mathrm{P}+\mathrm{C}$ of 25 and $50 \%$ with the highest $\mathrm{P}$-concentration (Figure $3 \mathrm{~B}$ ). High P:C ratios at high $\mathrm{P}+\mathrm{C}$ concentration (protein concentration $>20 \%$ ) resulted in low survival rates. Larval yield showed very strong linear, quadratic and interaction effects of protein and carbohydrates $(P<0.001)$ (Table 1$)$. Larval yield was highest on the diets with highest carbohydrate concentration at 50 and $75 \% \mathrm{P}+\mathrm{C}$. However, larval yield was low at all $5 \% \mathrm{C}$, being even lower at lower P:C ratio (Figure 3C).

\section{Larval body composition}

Larval crude protein is affected in a linear fashion by dietary protein $(P=0.028$; Table 2$)$. Higher dietary P levels lead to lower larval crude protein values (Figure 4A). Larval crude fat is very well explained by the model $\left(R^{2}=0.95\right)$
Table 1. Response surface model significance shown as $P$-values ( $F$ values in parentheses) for the full model $\left(F_{21,44}\right)$, for the linear effects of $P$ (protein content) and $C$ (carbohydrate content), their interactions $(P \times C)$ and quadratic terms $\left(P^{2}, C^{2}\right)$ for the larval performance variables survival rate, development time and larval yield $\left(F_{1,44}\right)$; LOF = lack of fit of the quadratic response model. Significance level was set at $P<0.05$.

\begin{tabular}{|c|c|c|c|}
\hline Source & Survival rate ${ }^{1}$ & Development time ${ }^{1,2}$ & Larval yield \\
\hline Full model & $<0.001(11.9)$ & $<0.001(20.8)$ & $<0.001(12.9)$ \\
\hline$P$ & $<0.001(90.4)$ & $<0.001(61.7)$ & $<0.001(13.1)$ \\
\hline C & $<0.001(30.9)$ & $<0.001(18.0)$ & $<0.001(23.6)$ \\
\hline$P \times C$ & $0.008(7.71)$ & $<0.001(114.1)$ & $<0.001(69.8)$ \\
\hline$P^{2}$ & $0.008(7.86)$ & $<0.001(206.1)$ & $<0.001(26.8)$ \\
\hline$C^{2}$ & $0.167(1.97)$ & $0.0034(9.60)$ & $<0.001(19.7)$ \\
\hline LOF & $0.024(2.16)$ & $0.1282(1.55)$ & $0.016(2.28)$ \\
\hline
\end{tabular}



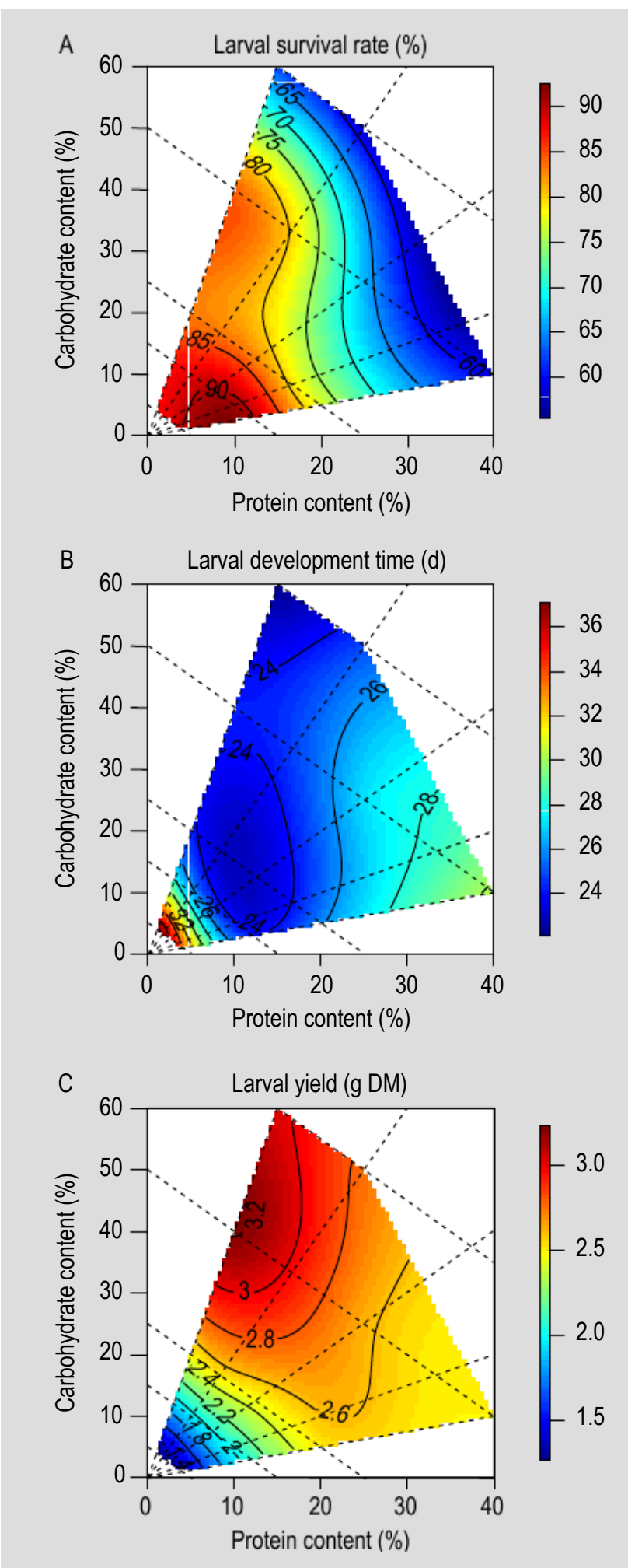

Figure 3. Black soldier fly larval performance on diets differing in $P+C$ concentration and $P: C$ ratio shown as thin-plate spline response surface graphs. (A) survival rate (\%); (B) development time (days), using -Log (carbohydrate \%) and Log (protein \%) as regressors (contour plot on original regressors scale); and (C) larval yield (g DM). A fitness landscape corresponding to insect response to each diet has been fitted over nutrient space; contour lines delimit colour areas going from the lowest (green) to highest (orange) values calculated for each performance variable. Black points indicate 22 experimental diets. and shows the strongest linear effect for protein and less for carbohydrate (both $P<0.001$; Table 2). The interaction effect and quadratic effect of $P$ are also significant (Table 2). Larval crude fat is high on diets with high $\mathrm{P}$ concentration; on diets with low $\mathrm{P}$-concentration larval crude fat increases with $\mathrm{C}$-concentration, but this relationship vanishes at higher values of $\mathrm{P}$ (Figure 4B).

\section{Adult life-history traits}

Larvae were not able to reach the adult stage at $50 \%$ and 4:1 ratio (40\% protein concentration). Therefore, this treatment was excluded from the analyses. Adult emergence percentage showed strong quadratic relationships with dietary $\mathrm{P}$ - and $\mathrm{C}$-concentrations, as well as by their interaction (all $P<0.001)$ (Table 3$)$.

Lowest adult emergence was observed at $\mathrm{P}+\mathrm{C}$ concentrations of 5 and $75 \%$, and $50 \%$ when the $P: C$ ratio was 2:1. However, high $P: C$ ratios increased adult emergence at $\mathrm{P}+\mathrm{C} 5 \%$ (Figure 5A). Development time was strongly affected in a linear fashion by protein and carbohydrate, their interaction, and a quadratic effect of carbohydrate was seen (Table 3). Development was slowest on P+C 5\%, and shorter at higher protein concentration. Although development was faster on $\mathrm{P}+\mathrm{C}$ values of 25,50 and $75 \%$, higher protein concentration did not accelerate it (Figure $5 \mathrm{~B})$. Individual adult weight showed a strong linear effect of carbohydrates $(P<0.001)$, and less so for protein $(P=0.006)$, smaller interaction and quadratic protein effects were also significant (Table 3). Similar to larval yield, adult weight was highest on the diets with highest $\mathrm{C}$-concentration at $\mathrm{P}+\mathrm{C} 50$ and $75 \%$, and low at all $\mathrm{P}+\mathrm{C} 5 \%$ diets, mainly at low $\mathrm{P}: \mathrm{C}$ ratios (Figure $5 \mathrm{C}$ ). Females are heavier than males $\left(\mathrm{t}_{(112)}=2.05 ; P<0.05\right)$. Adult longevity was affected

Table 2. Response surface significance shown as $P$-values ( $F$-values between parentheses) for the full model $\left(F_{20,31}\right)$, for the linear effects of $P$ (protein content) and $C$ (carbohydrate content), their interactions $(P \times C)$ and quadratic terms $\left(P^{2}, C^{2}\right)$ for larval body protein and fat contents $\left(\mathrm{F}_{1,31}\right)$; LOF = lack of fit of the quadratic response model. Significance level was set at $P<0.05$.

\begin{tabular}{|c|c|c|}
\hline Source & Larval crude protein ${ }^{1}$ & Larval crude fat \\
\hline Full model & $0.006(2.72)$ & $<0.001(28.7)$ \\
\hline$P$ & $0.028(5.31)$ & $<0.001(268.5)$ \\
\hline C & $0.024(1.85)$ & $<0.001(78.0)$ \\
\hline $\mathrm{PxC}$ & $0.35(0.88)$ & $0.041(4.6)$ \\
\hline$P^{2}$ & $0.22(1.59)$ & $<0.001(16.5)$ \\
\hline$C^{2}$ & $0.44(0.63)$ & $0.003(10.4)$ \\
\hline LOFa & $0.03(2.25)$ & $0.013(2.60)$ \\
\hline
\end{tabular}



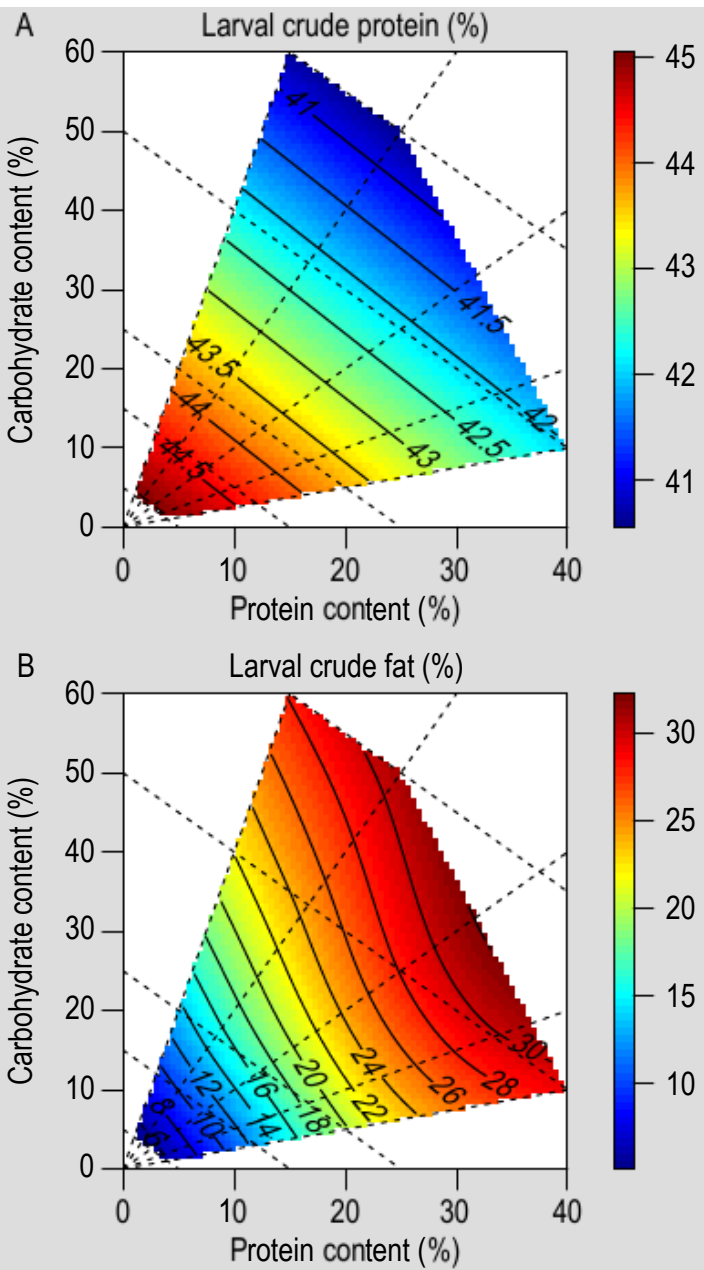

Figure 4. Black soldier fly larval body composition on different $P$ and $C$ concentrations and $P: C$ ratios shown as thin-plate spline response surface graphs. $(A)$ larval crude protein (\%); and (B) larval crude fat (\%). A fitness landscape corresponding to insect response to each diet has been fitted over nutrient space; contour lines delimit colour areas going from the lowest (green) to highest (orange) values calculated for each performance variable. Black points indicate 22 experimental diets. in a linear fashion by carbohydrate (Table 3). Adults lived shorter at $5 \% \mathrm{P}+\mathrm{C}$ and longer at $\mathrm{P}+\mathrm{C} 50$ and $75 \%$ at $1: 2$ and 1:4 ratios (Figure 5D). Females lived longer than males $\left(t_{112)}=2.16 ; P<0.05\right)$. Number of egg masses and egg yield were strongly affected in a linear fashion by carbohydrate, and small quadratic protein effects were also significant (Table 3). The highest number of egg masses was found on $\mathrm{P}+\mathrm{C} 50 \%$ at $1: 2$ and $1: 4$ ratios. The highest number of egg masses was found for flies reared on diets with a 1:4 ratio at most $\mathrm{P}+\mathrm{C}$ concentrations $(5,25,50$ and $75 \%)$, for $\mathrm{P}+\mathrm{C} 15 \%$ this was at the $1: 2$ ratio (Figure $5 \mathrm{E}$ ). The highest egg yield was found on $\mathrm{P}+\mathrm{C} 50 \%$ at $1: 4$ ratio. The highest egg yield found on $\mathrm{P}+\mathrm{C} 50$ and $75 \%$ was at $1: 4$ ratio, for $\mathrm{P}+\mathrm{C} 15 \%$ at $1: 2$ ratio, for $\mathrm{P}: \mathrm{C} 5 \%$ at $4: 1$ and for $\mathrm{P}+\mathrm{C} 25 \%$ at 1:1 ratio (Figure 5F). There was a significant relationship between egg mass surface and adult weight (Pearson test, $\mathrm{r}=0.72, P<0.05$ ), and adult weight and longevity (Pearson correlation test, $\mathrm{r}=0.69, P<0.05)$. Regarding the proxy of the rate of population growth $\left(r_{\mathrm{p}}\right)$, it was only lightly affected in a linear fashion by carbohydrate concentration, and in a quadratic fashion by protein concentration (Table 3 ). The highest rates of population growth were found at $\mathrm{P}+\mathrm{C}$ values of 50 and $75 \%$ and $1: 2$ and $1: 4$ ratios, at $P+C 25 \% 1: 1$ and 1:4 ratios and $\mathrm{P}+\mathrm{C} 15 \%$ 1:2 (Figure 5G).

\section{Discussion}

Our analysis of the relative importance of concentrations and ratio of dietary protein and carbohydrate demonstrated that BSF performance was more strongly affected by total dietary concentration of carbohydrate and protein $(\mathrm{P}+\mathrm{C})$ than by $\mathrm{P}: \mathrm{C}$ ratios. Cammack and Tomberlin (2017) examined the impact of artificial diets at one $\mathrm{P}+\mathrm{C}$ concentration (42\%) for three P:C ratios (1:1, $1: 5$ and 5:1) on life history traits of BSF, finding similar performance for the three $\mathrm{P}: \mathrm{C}$ ratios. Twenty combinations of $\mathrm{P}$ and $\mathrm{C}$ concentrations in the ranges $16-26 \% \mathrm{P}$ and $45-58 \% \mathrm{C}$ were

Table 3. Response surface significance shown as $P$-values ( $F$ values between parentheses) for the full model $\left(F_{20,33) \text {, and for }}\right.$ linear effects of $P$ (protein content) and $C$ (carbohydrate content), their interactions $(P \times C)$ and quadratic terms $\left(P^{2}, C^{2}\right)$ for adult performance measurements $\left(F_{1,33}\right)$; LOF = lack of fit of the quadratic response model. Significance level was set at $P<0.05$.

\begin{tabular}{|c|c|c|c|c|c|c|c|}
\hline Source & $\begin{array}{l}\text { Adult } \\
\text { emergence }\end{array}$ & $\begin{array}{l}\text { Development time } \\
\text { until adult stage }{ }^{1}\end{array}$ & $\begin{array}{l}\text { Individual adult } \\
\text { weight }\end{array}$ & Adult longevity & $\begin{array}{l}\text { Number of } \\
\text { egg masses }\end{array}$ & Egg yield & $r_{\mathrm{p}}{ }^{2}$ \\
\hline Full model & $<0.001(11.2)$ & $<0.001(11.7)$ & $<0.001(5.00)$ & $0.088(1.69)$ & $0.056(1.85)$ & $<0.001(3.39)$ & $0.013(2.38)$ \\
\hline$P$ & $0.038(4.66)$ & $<0.001(46.4)$ & $0.006(8.71)$ & $0.225(1.53)$ & $0.490(0.49)$ & $0.425(0.65)$ & $0.964(0.002)$ \\
\hline C & $0.425(0.65)$ & $<0.001(15.3)$ & $<0.001(25.3)$ & $0.021(5.91)$ & $<0.001(15.5)$ & $<0.001(35.4)$ & $0.005(8.94)$ \\
\hline PxC & $<0.001(58.1)$ & $<0.001$ (33.1) & $0.007(8.42)$ & $0.236(1.46)$ & $0.079(3.28)$ & $0.082(3.22)$ & $0.059(3.82)$ \\
\hline$P^{2}$ & $<0.001(89.9)$ & $<0.001(22.1)$ & $0.006(8.51)$ & $0.067(3.60)$ & $0.044(4.38)$ & $0.012(7.01)$ & $<0.001(14.5)$ \\
\hline$c^{2}$ & $<0.001(54.4)$ & $0.004(9.41)$ & $0.363(0.85)$ & $0.720(0.13)$ & $0.208(1.65)$ & $0.468(0.54)$ & $0.228(1.51)$ \\
\hline LOF & $<0.001(4.54)$ & $<0.001(5.80)$ & $0.335(1.18)$ & $0.533(0.94)$ & $0.846(0.61)$ & $0.711(0.76)$ & $0.893(0.58)$ \\
\hline
\end{tabular}

${ }^{1}$ Logarithmic regressors were used.

2 Proxy for rate of population growth. 


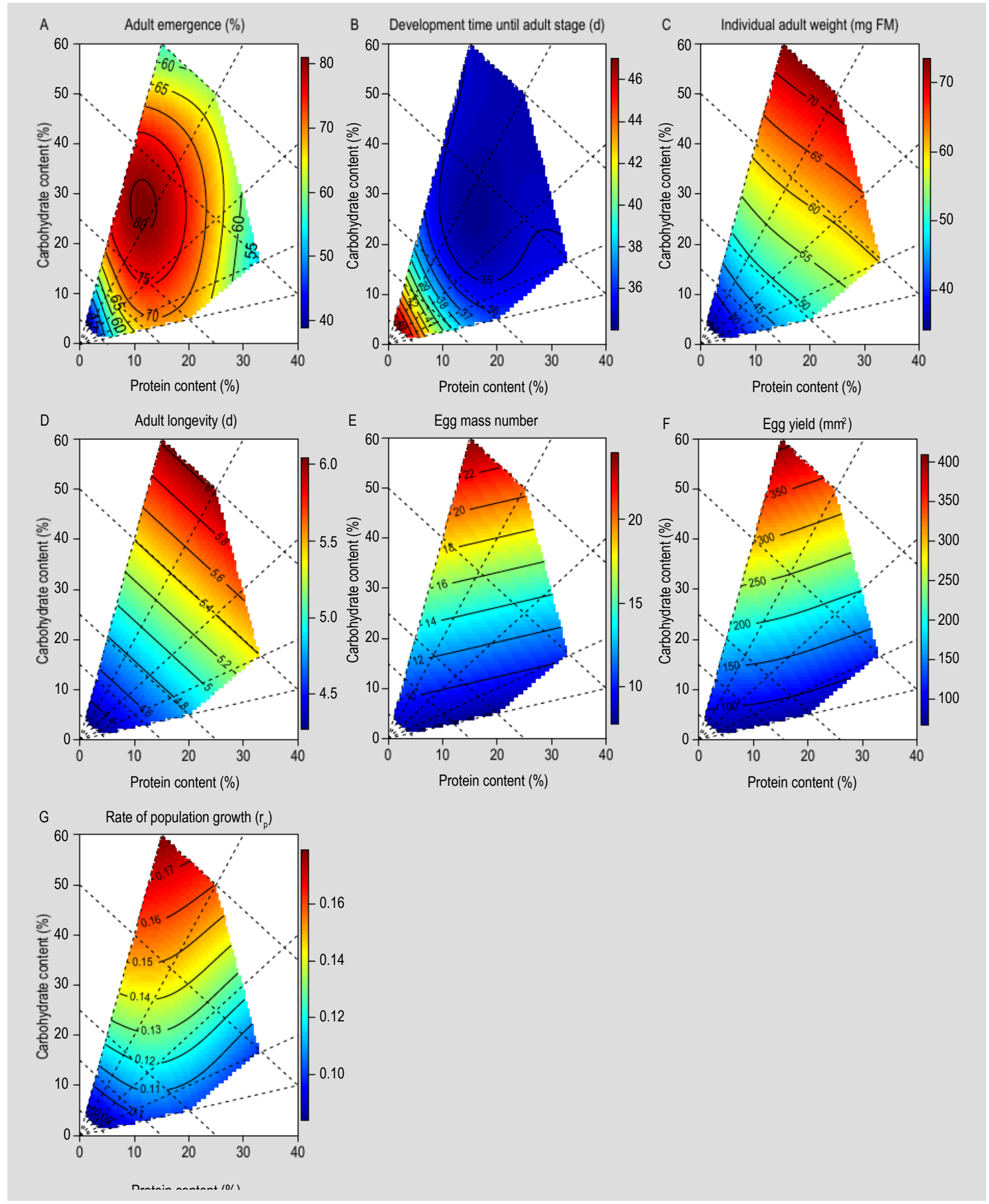

Figure 5. Black soldier fly adult performance on different $P$ and $C$ concentrations and $P: C$ ratios shown as thin-plate spline response surface graphs. (A) adult eclosion (\%); (B) development time until adult stage (D), using -Log (carbohydrate \%) and Log (protein \%) as regressors (contour plot on original regressors scale); (C) individual adult weight (mg FM); (D) adult longevity (days); (E) number of egg masses per treatment group; (F) egg yield $\left(\mathrm{mm}^{2}\right)$; and (G) proxy of intrinsic rate of population growth. A fitness landscape corresponding to insect response to each diet has been fitted over nutrient space; contour lines delimit colour areas going from the lowest (green) to highest (orange) values calculated for each performance variable. Black points indicate 22 experimental diets. 
tested for nutritional suitability for BSF larvae by adding crude protein and starch sources to chicken feed (Beniers and Graham, 2019). Highest larval yield was obtained at $23 \% \mathrm{P}$ and $53 \% \mathrm{C}$, which is at a higher $\mathrm{P}$ concentration than in the present study; this is likely explained by the plant protein in the chicken feed that has a lower nutritional quality than the casein we tested. The artificial diet may not have been optimal for BSF performance; in our study it served as a nutritional background for assessing the effects of $\mathrm{P}$ and $\mathrm{C}$ concentrations.

For larval crude fat, larval yield, and adult weight, the surface-response models reveal that a high percentage of variation $(>80 \%,>60 \%$ and $>55 \%$ respectively) is due to dietary $\mathrm{P}+\mathrm{C}$ concentration. $\mathrm{P}: \mathrm{C}$ ratio contributed little to explained variation of the 12 performance variables quantified, the maximum being $12 \%$ for the number of egg masses produced per female. The importance of $\mathrm{P}$-concentration alone, $\mathrm{C}$-concentration alone or their interaction $(\mathrm{P} \times \mathrm{C})$ differs between the larval and adult stage. For example, P-concentration had a stronger effect than C-concentration on larval performance, specifically development time, survival rate, and larval body protein concentration, whereas $\mathrm{C}$-concentration had a stronger effect than P-concentration on adult weight and total egg production.

\section{Larval life-history traits}

Our results show that larvae can deal with a wide range of nutrient concentrations, however, a P-concentration higher than $37 \%$ reduced their performance. Excess of dietary protein has been found to lower survival rate of BSF in some studies. For example, BSF larvae reared on diets high in protein (32-50\% crude protein on DM basis) such as dried distillers grains with solubles, meat meal, liver or fish experienced high mortality $(78,80,43$ and $53 \%$ respectively) (Tschirner and Simon, 2015). This may be explained by an excessive energy use for excreting or metabolising the excess of amino acids and/or uric acid. Dipteran species excrete the water-soluble allantoin, the immediate degradation product of uric acid, which is converted to urea, and by the action of urease to ammonium (Green and Popa, 2012). BSF larvae fed on high protein diets $(>15 \%)$ may have an elevated faecal ammonium concentration, which increases potential harmful ammonia emissions.

High P-concentration accelerated larval development at low $\mathrm{P}+\mathrm{C}$ concentrations whereas at high $\mathrm{P}+\mathrm{C}, \mathrm{C}$-concentration accelerates development when $\mathrm{P}$-concentration suffices to cover larval needs (8-17\%). In other studies on BSF, shorter development times were recorded at high dietary nutrient levels (Barragan-Fonseca et al., 2017a) and high P-concentration (Nguyen et al., 2013; Oonincx et al., 2015). We suggest that BSF larvae develop faster on low $\mathrm{P}+\mathrm{C}$ if protein concentration is not limiting. BSF larvae fed on diets with high $\mathrm{P}: \mathrm{C}$ ratios and low $\mathrm{P}+\mathrm{C}$ concentrations might use protein more efficiently, as is seen for other insects with symbionts (Gold et al., 2018; Raubenheimer and Simpson, 2003). Since the fastest development was observed at $15 \%$ $\mathrm{P}+\mathrm{C}$, we infer that BSF larvae trade-off developing faster over growing bigger because fast development resulted in individuals having lower biomass, as long as larvae are provided with enough protein to grow $(7-12 \%)$. In the case of BSF fed on diets of varying resource quality and increasing level of competition, fitness benefits may be gained by developing rapidly into adults, to avoid increased mortality due to food shortage, larval predation, parasitism (Kaspi et al., 2002; Lee et al., 2006).

When carbohydrates are in excess, we hypothesise that BSF larvae are able to use post-ingestive physiological mechanisms as they performed well on carbohydrate-biased diets at high $\mathrm{P}+\mathrm{C}$ concentrations (C-concentration 40-60\%), and no deleterious effects were seen due to carbohydrate excess. We conclude that BSF larvae can handle excess of carbohydrates and hypothesise that they convert them to lipids for storage in their fat body (Gold et al., 2018).

\section{Larval body composition}

Larval body crude protein concentration is affected by $\mathrm{P}+\mathrm{C}$-concentration of the diet, $\mathrm{P}$ and $\mathrm{C}$ contributing equally, and by the interaction between $\mathrm{P}+\mathrm{C}$-concentration and $\mathrm{P}: \mathrm{C}$ ratio. Larval crude protein concentration (range 38.2-46.5\% DM) was similar to values found in previous studies for larvae fed on nutritionally diverse diets such as chicken feed, by-products of food manufacturing, manure and semi-artificial diets $(43.2 \pm 2.7 \% \mathrm{DM})$ (Barragan-Fonseca et al., 2017a,b). The current data confirm that larval $\mathrm{P}$-concentration is regulated within narrow limits.

In contrast, larval crude fat concentration exhibited a large variation among the 25 diets (range $3.0-32.7 \% \mathrm{DM}$ ) and was affected by $\mathrm{P}+\mathrm{C}$ concentration that explained $85 \%$ of variation, of which $\mathrm{P}$-concentration alone contributed $70 \%$. Crude fat was high at 25 and $50 \% \mathrm{P}+\mathrm{C}$. Sufficient protein provided to BSF larvae promoted lipid storage and thereby enhances reproduction capacity, as well as the expression of key genes involved in these metabolic processes (Pimentel et al., 2017). However, although high P-concentration at $\mathrm{P}+\mathrm{C} 50 \%$ increased larval yield, the larvae did not develop into adults. In plant-feeding insect species $\mathrm{C}$-concentration seems to play a more prominent role than protein. For example, in grasshopper Melanoplus differentialis (Le Gall and Behmer, 2014), and Heliothis virescens caterpillars (Roeder, 2010), high dietary carbohydrate levels increased insect weight. In addition, P-concentration can also have an important effect on low C-concentration diets, as is the case for larval Manduca sexta that, in the absence of dietary carbohydrate, maintains blood trehalose level by gluconeogenesis which is dependent on dietary protein 
consumption. Thus, when carbohydrates are limiting and protein is in excess, using excess amino acids for gluconeogenesis is an option (Thompson, 2004).

\section{Adult life-history traits}

Acquisition of nutrients during larval development of holometabolous species significantly affects physiological processes of adult insects (Boggs and Freeman, 2005; Hahn, 2005; Jones and Raubenheimer, 2001; Prabhu et al., 2008; Roeder and Behmer, 2014; Waldbauer et al., 1984). Although adult BSF do not require food to survive or produce eggs, adult longevity is increased when provided with a source of water (Tomberlin and Sheppard, 2002), and sugar (Nakamura et al., 2016) or honey (Rachmawati et $a l ., 2010)$. It should be noted that longevity was measured under water and sugar deprivation, whereas the flies of which egg production was determined did have ad libitum access to water and sugar, a difference which may affect correct interpretation. High $\mathrm{P}+\mathrm{C}$-diets and low $\mathrm{P}: \mathrm{C}$ ratios promoted heavier adults and increased egg production, probably because in BSF, larger females have larger numbers and sizes of ovarioles (Gobbi et al., 2013). We found a positive correlation between adult weight and egg yield. As was mentioned before, this could be related to lipogenesis, which could be more beneficial for females because lipids are an important egg component (Chapman et al., 2013), and it explains that egg yield and egg mass number were more affected by $\mathrm{C}$-concentration than by $\mathrm{P}$-concentration. Besides the fact that heavier females produce more offspring (Danks, 2013), longevity can have an important role in increasing fitness of polyandric insects like BSF, as females gain directly from multiple matings in terms of increased lifetime offspring production (Arnqvist and Nilsson, 2000). In this study there was a significant positive relationship between adult weight and longevity.

Here we document the degree of deviation in performance variables and body protein and lipid concentrations of the generalist saprophagous BSF in response to a wide range of $\mathrm{P}$ - and $\mathrm{C}$-concentrations. The application of the Nutritional Geometry Framework revealed differences in the effects of $\mathrm{P}$ and $\mathrm{C}$-concentration between larval and adult performance measurements. For example, whereas larval survival was optimal at P $10 \%$ and C $40 \%$, individual adult weight was highest at $\mathrm{P} 10 \%$ and $\mathrm{C} 60 \%$ and life-time reproduction at $\mathrm{P} 15 \%$ and $\mathrm{C} 60 \%$. In our experiments BSF larvae did not have the opportunity to self-select a mixture of nutrients that would allow them to diminish such tradeoffs, which is also the situation in mass-rearing conditions.

Our study demonstrates that BSF can handle diets containing a wide range of $\mathrm{P}$ and $\mathrm{C}$ concentrations and $\mathrm{P}: \mathrm{C}$ ratios, pointing at a remarkable degree of nutritional plasticity. Our study is the first that applied response surface modelling to investigate the effects of a wide range of protein and carbohydrate concentrations, including strongly protein- and digestible carbohydrate-biased diets, on life-history traits in BSF using chemically defined diets. The response surface analysis revealed that $\mathrm{P}+\mathrm{C}$ values of 25 and 50\%, and P:C ratios of 1:2 and 1:4 resulted in the highest values of most of the larval and adult performance variables we measured. However, diet composition optimal for adult emergence and egg production differ from those optimal for mass production of larval biomass or larval protein content. It is important to emphasise that these outcomes are valid for the protein (casein) and digestible carbohydrate (starch) we tested and may turn out different for other types of proteins and carbohydrates.

\section{Acknowledgements}

We thank Seppe Salari for assistance with the experiments and Leon de Jonge of the Laboratory of Animal Nutrition of Wageningen University for the chemical analysis of nutrient concentrations. This work was supported by the Scholarship Program no. 568 from COLCIENCIAS - Departamento Administrativo de Ciencia, Tecnología e Innovación, Colombia.

\section{Conflict of interest}

The authors declare no conflict of interest.

\section{References}

Arnqvist, G. and Nilsson, T., 2000. The evolution of polyandry: multiple mating and female fitness in insects. Animal Behaviour 1: 145-164.

Barragán-Fonseca, K.B, Dicke, M. and Van Loon J.J.A., 2017a. Influence of larval density and nutrient concentration on performance and body protein and fat composition of Hermetia illucens larvae. Entomologia Experimentalis et Applicata 166: 761-770.

Barragán-Fonseca, K.B., Dicke, M. and Van Loon J.J.A., 2017b. Nutritional value of the black soldier fly (Hermetia illucens L.) and its suitability as animal feed - a review. Journal of Insects as Food and Feed 3: 105-120.

Barragán-Fonseca, K.B., Gort, G., Dicke, M., Van Loon, J.J.A., 2019. Effects of dietary protein andcarbohydrate on life-history traits and body protein and fat concentrations of the black soldier fly Hermetia illucens. Physiological Entomology 44: 148-159.

Beniers, J.A.A. and Graham, R.I., 2019. Effect of protein and carbohydrate feed concentrations on the growth and composition of black soldier fly (Hermetia illucens) larvae. Journal of Insects as Food and Feed 5: 193-199.

Boggs, C.L. and Freeman, K.D., 2005. Larval food limitation in butterflies: effects on adult resource allocation and fitness. Oecologia 144: 353-361.

Cammack, J.A. and Tomberlin, J.K., 2017. The impact of diet protein and carbohydrate on select life-history traits of the black soldier fly Hermetia illucens (L.) (Diptera: Stratiomyidae). Insects: 8: 56. 
Chapman, R.F., Simpson, S.J. and Douglas, A.E. (eds.), 2013. The insects: structure and function. Cambridge University Press, Cambridge, UK, 770 pp.

Cohen, A.C., 2004. Insect diets: science and technology. CRC Press, New York, NY, USA

Danks, H.V., 2013. Insect life-cycle polymorphism: theory, evolution and ecological consequences for seasonality and diapause control. Springer Science \& Business Media, Berlin, Germany.

Gobbi, P., Martínez-Sánchez, A. and Rojo, S., 2013. The effects of larval diet on adult life-history traits of the black soldier fly, Hermetia illucens (Diptera: Stratiomyidae). European Journal of Entomology 110: 461-468.

Gold, M., Tomberlin, J.K., Diener, S., Zurbrügg, S. and Mathys, A., 2018. Decomposition of macronutrients, microbes and chemicals in black soldier fly larval treatment: a review. Waste Management 82: 302-318.

Green, T.R. and Popa, R., 2012. Enhanced ammonia concentration in compost leachate processed by black soldier fly larvae. Applied Biochemistry and Biotechnology 166: 1381-1387.

Hahn, D.A., 2005. Larval nutrition affects lipid storage and growth, but not protein or carbohydrate storage in newly eclosed adults of the grasshopper Schistocerca americana. Journal of Insect Physiology 51: 1210-1219.

Jones, S. and Raubenheimer, D., 2001. Nutritional regulation in nymphs of the German cockroach, Blattella germanica. Journal of Insect Physiology 47: 1169-1180.

Kaspi, R., Mossinson, S., Drezner, T., Kamensky, B. and Yuval, B., 2002. Effects of larval diet on development rates and reproductive maturation of male and female Mediterranean fruit flies. Physiological Entomology 27: 29-38.

Le Gall, M. and Behmer, S.T., 2014. Effects of protein and carbohydrate on an insect herbivore: the vista from a fitness landscape. Integrative and Comparative Biology 54: 942-954.

Lee, K.P., Behmer, S.T. and Simpson, S.J., 2006. Nutrient regulation in relation to diet breadth: a comparison of Heliothis sister species and a hybrid. Journal of Experimental Biology 209: 2076-2084.

Lenth, R.V., 2009. Response-surface methods in R, using rsm. Journal of Statistical Software 32: 1-17.

Lihoreau, M., Buhl, J., Charleston, M.A., Sword, G.A., Raubenheimer, D. and Simpson, S.J., 2015. Nutritional ecology beyond the individual: a conceptual framework for integrating nutrition and social interactions. Ecology Letters 18: 273-286.

May, B., 1961. The occurrence in New Zealand and the life-history of the soldier fly Hermetia illucens (L.)(Diptera: Stratiomyidae). The New Zealand Journal of Science and Technology 4: 55-65.

Nakamura, S., Ichiki, R.T., Shimoda, M. and Morioka, S., 2016. Smallscale rearing of the black soldier fly, Hermetia illucens (Diptera: Stratiomyidae), in the laboratory: low-cost and year-round rearing. Applied Entomology and Zoology 51: 161-166.

Nguyen, T.T., Tomberlin, J.K. and Vanlaerhoven, S., 2013. Influence of resources on Hermetia illucens (Diptera: Stratiomyidae) larval development. Journal of Medical Entomology 50: 898-906.
Nychka, D., Furrer, R., Paige, J. and Sain, S., 2017. Package 'fields': tools for spatial data. R package version 9.6. https://doi.org/10.5065/ D6W957CT

Oonincx, D.G.A.B., Van Broekhoven, S., Van Huis, A. and Van Loon, J.J.A., 2015. Feed conversion, survival and development, and composition of four insect species on diets composed of food byproducts. PLoS ONE 10: e0144601.

Pimentel, A.C., Montali, A., Bruno, D. and Tettamanti, G., 2017. Metabolic adjustment of the larval fat body in Hermetia illucens to dietary conditions. Journal of Asia-Pacific Entomology 20: 13071313.

Prabhu, V., Perez-Staples, D. and Taylor, P., 2008. Protein: carbohydrate ratios promoting sexual activity and longevity of male Queensland fruit flies. Journal of Applied Entomology 132: 575-582.

Price, P.W., 1997. Insect ecology ( $3^{\text {rd }}$ Ed.). John Wiley, New York, NY, USA, $874 \mathrm{pp}$.

R-core-team, 2017. R: a language and environment for statistical computing. R Foundation for Statistical Computing, Vienna, Austria.

Rachmawati, R., Buchori, D., Hidayat, P., Hem, S. and Fahmi, M.R., 2010. Perkembangan dan kandungan nutrisi larva Hermetia illucens (Linnaeus) (Diptera: Stratiomyidae) pada bungkil Kelapa Sawit. Jurnal Entomologi Indonesia 7: 28-41.

Raubenheimer, D. and Simpson, S.J., 1997. Integrative models of nutrient balancing: application to insects and vertebrates. Nutrition Research Reviews 10: 151-179.

Raubenheimer, D. and Simpson, S.J., 2003. Nutrient balancing in grasshoppers: behavioural and physiological correlates of dietary breadth. The journal of Experimental Biology 206: 1669-1681.

Raubenheimer, D. and Simpson, S.J., 2018. Nutritional ecology and foraging theory. Current Opinion in Insect Science 27: 38-45.

Roeder, K.A., 2010. Dietary effect on the performance and body composition of the generalist insect herbivore, Heliothis virescens (Lepidoptera: Noctuidae). MSc thesis, Texas A\&M University, College Station, TX, USA. Available at: https://tinyurl.com/ y557wtw2.

Roeder, K.A. and Behmer, S.T., 2014. Lifetime consequences of food protein-carbohydrate concentration for an insect herbivore. Functional Ecology 28: 1135-1143.

Thompson, S., 2004. Dietary fat mediates hyperglycemia and the glucogenic response to increased protein consumption in an insect, Manduca sexta L. Biochimica et Biophysica Acta 1673: 208-216.

Tomberlin, J.K. and Sheppard, D.G., 2002. Factors influencing mating and oviposition of black soldier flies (Diptera: Stratomyidae) in a colony. Journal of Entomological Society 37: 345-352.

Tschirner, M. and Simon, A., 2015. Influence of different growing substrates and processing on the nutrient composition of black soldier fly larvae destined for animal feed. Journal of Insects as Food and Feed 1: 249-259.

Waldbauer, G.P., Cohen, R.W. and Friedman, S., 1984. Self-selection of an optimal nutrient mix from defined diets by larvae of the cornearworm, Heliothis zea (Boddie). Physiological Zoology 57: 590-597. 